\title{
Effectivness of Micropore Tape in Treatment of Hypertrophic Scar after Wrist Burn
}

\author{
WAFAA BORHAN, Ph.D.*; NESSRIEN A. ABDEL RASHID, Ph.D.*; WAEL N. THABET, M.D.** and \\ AHMED R.A. Ali, M.Sc.* \\ The Department of Physical Therapy for Surgery \& Burn, Faculty of Physical Therapy* and \\ The Department of General Surgery, Faculty of Medicine**, Cairo University, Egypt
}

\begin{abstract}
Background: Burns are caused by exposure to excessive heat as flame, hot surfaces, scalding liquids, friction, electricity and chemical burns. Hypertrophic scarring is a frequent and undesirable complication of burn injuries.
\end{abstract}

Aim of Study: This study was conducted to investigate the effectiveness of micropore tape in treatment of hypertrophic scar after wrist burn.

Subjects and Methods: Thirty patients complaining of hypertrophic scar after wrist burn selected from learning hospitals (Al-Kaser Al-Ayni Hospital and Om El-Masryeen Hospital) in Cairo shared in this study. Their ages were ranged from 20 to 45 years. Patients who are suffering from malignant tumors, patients with 3 rd degree burns of wrist and patients with major burns covering more than $20 \%$ of TBS were excluded from this study. They were divided into two equal groups: Group (A) who received micropore tape treatment in addition to normal physical therapy program (stretching exercises and strengthening exercises), routine medical treatment and traditional care (dressing) 30 minutes 3 sessions/ week for 12 weeks. Group B who received normal physical therapy program (stretching exercises and strengthening exercises), routine medical treatment and traditional care (dressing) 30 minutes 3 sessions/ week for 12 weeks. Pigmentation, vascularity, pliability and height were measured by Vancouver scar scale.

Results: The results showed that there is significant difference in Vancouver scar scale in group A pre and post treatment and there is significant difference in Vancouver scar scale in group B pre and post treatment and there is a significant difference in Vancouver scar scale between group $\mathrm{A}$ and $\mathrm{B}$ pre and post treatment as group $\mathrm{A}$ improved more than group B.

Conclusion: It can be concluded that micropore tape with physical therapy treatment has an effect on hypertrophic scar after wrist burn more than physical therapy only.

Key Words: Micropore tape - Hypertrophic scare - Wrist burn.

Correspondence to: Dr. Wafaa Borhan, The Department of Physical Therapy for Surgery \& Burn, Faculty of Physical Therapy, Cairo University, Egypt

\section{Introduction}

BURNS are caused by exposure to excessive heat as flame, hot surfaces, scalding liquids, friction, electricity and chemical burns [1]

The basic pathophysiological consequence of the burn injury is the loss of the capillary integrity, localized increase in the micro vascular permeability, generalized impairment in the cell membrane resulting in swelling and increase osmotic press. Of the burned tissue leading to further fluid accumulation and edema formation, which is a result of the outpouring of the intravascular fluid into the interstitial spaces [2].

Hypertrophic scars occur when the body overproduces collagen, which causes the scar to be raised above the surrounding skin. Hypertrophic scars take the form of a red raised lump on the skin. They usually occur within 4 to 8 weeks following wound infection or wound closure with excess tension and/or other traumatic skin injuries [3].

"Micro pore" is a trade mark for micro porous tape sold by $3 \mathrm{M}$; it is a self- adhesive tape which adheres to the skin when a contact medium has been applied to it. This provides a significant advantage over a fully occlusive material which promotes bacterial proliferation [4].

Micro porous paper tape is gaining attention in scar prevention. However, in current standard practice, paper tape is used for only a few weeks to support surgical scars after suture removal. It is proposed that long-term use of paper tape, until approximately 12 weeks after wounding, would allow maximum strength of scar, which would be beneficial in preventing hypertrophic scarring [5] 


\section{Subjects and Methods}

This study was conducted on thirty patients complaining of hypertrophic scar after wrist burn selected from learning hospitals (Al-Kaser Al-Ayni Hospital and Om El-Masryeen Hospital) in Cairo shared in this study. The study was conducted from March 2016 to April 2017. Their ages were ranged from 20 to 45 years. Patients who are suffering from malignant tumors, patients with 3 rd degree burns of wrist and patients with major burns covering more than $20 \%$ of TBS were excluded from this study. They were divided into two equal groups: Group (A) who received micropore tape treatment in addition to normal physical therapy program (stretching exercises and strengthening exercises), routine medical treatment and traditional care (dressing) 30 minutes 3 sessions/week for 12 weeks. Group (B) who received normal physical therapy program (stretching exercises and strengthening exercises), routine medical treatment and traditional care (dressing) 30 minutes 3 sessions/week for 12 weeks. Pigmentation, vascularity, pliability and height were measured by Vancouver scar scale.

\section{Procedures:}

All patients with burn were given a full explanation of the protocol of the study and consent form was signed for each patient before participating in the study.

\section{A- Evaluation procedures:}

Vancouver scar scale:

Is the most recognized burn scar assessment method, it assesses four variables: Vascularity, height, thickness, pliability and pigmentation.

\begin{tabular}{|c|c|c|c|}
\hline \multicolumn{2}{|c|}{ Pigmentation Vascularity } & \multirow{3}{*}{$\begin{array}{l}\text { Pliability } \\
\text { 0- Normal } \\
1-\text { Supple }\end{array}$} & \multirow{3}{*}{$\begin{array}{c}\text { Height } \\
0-\text { Normal } \\
1-<2 \mathrm{~mm}\end{array}$} \\
\hline 0 - Normal & 0- Normal & & \\
\hline $\begin{array}{l}\text { 1- Hypo- } \\
\text { pigmentation }\end{array}$ & 1- Pink & & \\
\hline \multirow{3}{*}{$\begin{array}{l}\text { 2- Hyper- } \\
\text { pimentation } 3\end{array}$} & $\begin{array}{l}\text { 2- Pink to red } 2 \\
\text { 3- Red }\end{array}$ & $\begin{array}{l}\text { - Yielding } \\
\text { 3- Firm }\end{array}$ & $\begin{array}{l}2-2-5 \mathrm{~mm} \\
3->5 \mathrm{~mm}\end{array}$ \\
\hline & 4- Red to purple & e 4- Banding & \\
\hline & 5- Purple & 5- Contracture & \\
\hline
\end{tabular}

Fig. (1): VSS.

\section{B- Treatment procedures:}

Group (A) who received micropore tape treatment in addition to normal physical therapy program (stretching exercises and strengthening exercises), routine medical treatment and traditional care (dressing) 30 minutes 3 sessions/week for 12 weeks.

Group (B) who received normal physical therapy program (stretching exercises and strengthening exercises), routine medical treatment and traditional care (dressing) 30 minutes 3 sessions/week for 12 weeks.

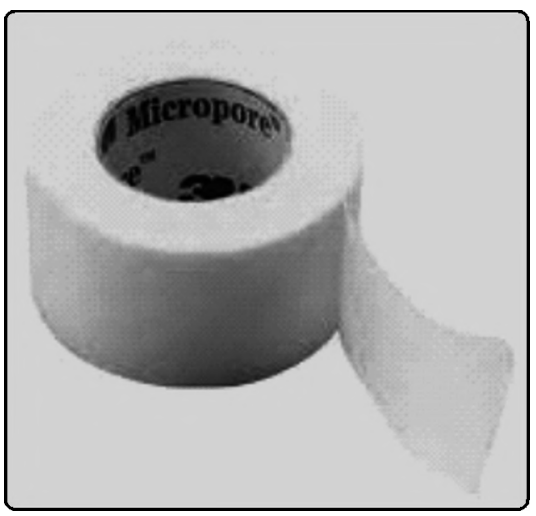

Fig. (2): Microrope Tape.

Statistical analysis:

Results are expressed as \pm standard deviation (SD) or number (\%). Comparison between the mean values of different variables pre and post treatment within groups was performed using paired student $t$ test. Comparison between the mean values of the different variables as regards post treatment in the two groups was performed using unpaired student $t$ test.

\section{Results}

\section{I- General characteristics of the patients:}

There was non significant difference between two groups (A and B) for "Age" as a ( $t$ ) value equal $(0.186)$ and the $p$-value is $(0.85)$, which more than (0.05).

Table (1): Physical characteristics of patients in both groups (A\&B).

\begin{tabular}{|c|c|c|c|c|c|c|}
\hline \multirow{2}{*}{$\begin{array}{l}\text { Signifi- } \\
\text { cance }\end{array}$} & \multirow{2}{*}{$\begin{array}{c}p- \\
\text { value }\end{array}$} & \multirow{2}{*}{\multicolumn{2}{|c|}{$t \mathbf{M D}$}} & \multirow{2}{*}{$\begin{array}{c}\text { Group } \\
\text { (B) } \\
\text { Mean } \pm \\
(\text { SD) }\end{array}$} & \multirow{2}{*}{$\begin{array}{l}\text { Group } \\
(\mathrm{A}) \\
\text { Mean } \pm \\
(\mathrm{SD})\end{array}$} & \multirow[t]{2}{*}{ Variables } \\
\hline & & & & & & \\
\hline NS & 0.85 & 0.186 & 0.67 & $\begin{array}{l}31.67 \pm \\
9.75\end{array}$ & $\begin{array}{l}31.0 \pm \\
9.85\end{array}$ & $\begin{array}{l}\text { Age } \\
\text { (month) }\end{array}$ \\
\hline $\begin{array}{l}\text { SD: Stanc } \\
\text { MD: Mea }\end{array}$ & $\begin{array}{l}\text { ard De } \\
\text { differe }\end{array}$ & $\begin{array}{l}\text { ation. } \\
\text { ce. }\end{array}$ & & $\begin{array}{l}\text { ue: Unpa } \\
\text { ue: Prob } \\
\text { Non sign }\end{array}$ & $\begin{array}{l}\text { ed } t \text {-valu } \\
\text { sility valu } \\
\text { icant. }\end{array}$ & \\
\hline
\end{tabular}

II- Vancover scar scale:

A- Within group:

Group A:

Results Within group (A): For variables study Wilcoxon Test: To test difference within group A to find a difference between treatment pre/post for variables vss. 
Table (2): Comparison between pre and post treatment (vss) (Standard score) for group (A) using Wilcoxon Test $(\mathrm{n}=15)$.

\begin{tabular}{lcccccc}
\hline Result & $\begin{array}{c}p- \\
\text { value }\end{array}$ & $\begin{array}{c}\text { Z- } \\
\text { value }\end{array}$ & $\begin{array}{c}\text { Mean } \\
\text { rank }\end{array}$ & $\begin{array}{c}\text { Post } \\
\text { median } \\
\text { (IQR) }\end{array}$ & $\begin{array}{c}\text { Pre } \\
\text { median } \\
\text { (IQR) }\end{array}$ & Variables \\
\hline Sig. & $0.01 * * 3.425$ & 8 & $5(4,6)$ & $8(6,10)$ & Vss \\
\hline
\end{tabular}

**Significant at the (.01) level.

There is statistically significant difference between treatment pre-post as a $(\mathrm{Z})$ value equal (3.425), with $p$-value $(0.01)$, which less than $(0.01)$. That for the benefit for (post) treatment Median equal (5), while Median (pre) treatment equal (8).

\section{Group B:}

Results Within group (B): For variables studyWilcoxon Test: to test difference within group B to find a difference between treatment pre/post for variables vss.

Table (3): Comparison between pre and post treatment values of vss (B) (Standard score) for group control using Wilcoxon Test $(n=15)$.

\begin{tabular}{lcccccc}
\hline \multirow{2}{*}{ Result } & $\begin{array}{c}p- \\
\text { value }\end{array}$ & $\begin{array}{c}\text { Z- } \\
\text { value }\end{array}$ & $\begin{array}{l}\text { Mean } \\
\text { rank }\end{array}$ & $\begin{array}{c}\text { Post } \\
\text { median } \\
(\text { IQR })\end{array}$ & $\begin{array}{c}\text { Pre } \\
\text { median } \\
(\text { IQR })\end{array}$ & Variables \\
\cline { 2 - 7 } Sig. & $0.01 * *$ & 3.497 & 8 & $9(6,10)$ & $10(7,13)$ & Vss \\
\hline
\end{tabular}

**Significant at the (.01) level.

There is statistically significant difference between treatment pre-post as a $(\mathrm{Z})$ value equal (3.497), with $p$-value (0.01), which less than (0.01). That for the benefit for (post) treatment Median equal (9), while Median (pre) treatment equal (10).

\section{B- Between groups:}

I- Groups (A and B) mean values of variables for Pre, post treatment Mann- Whitney Test.

Table (4): Compare the difference between groups (A and B) of variables study (Standard score) using MannWhitney Test $(n=15)$.

\begin{tabular}{lccccllll}
\hline Result & $\begin{array}{c}p- \\
\text { value }\end{array}$ & $\begin{array}{c}\text { Z- } \\
\text { value }\end{array}$ & $\begin{array}{c}\text { Mean } \\
\text { rank } \\
\text { B }\end{array}$ & $\begin{array}{c}\text { Mean } \\
\text { rank }\end{array}$ & $\begin{array}{l}\text { Median } \\
\text { (IQR) }\end{array}$ & $\begin{array}{l}\text { Median } \\
(\text { IQR })\end{array}$ & $\begin{array}{l}\text { Vari- } \\
\text { ables }\end{array}$ \\
\hline N.Sig. & 0.12 & 1.542 & 17.97 & 13.03 & $\begin{array}{l}10 \\
(7,13)\end{array}$ & $\begin{array}{l}8 \\
(6,10)\end{array}$ & $\begin{array}{l}\text { Vss- } \\
\text { Pre }\end{array}$ \\
Sig. & $0.003^{* *}$ & 2.963 & 20.23 & 10.77 & $\begin{array}{l}9 \\
(6,10)\end{array}$ & $\begin{array}{l}5 \\
(4,6)\end{array}$ & $\begin{array}{l}\text { Vss- } \\
\text { Post }\end{array}$ \\
\hline
\end{tabular}

**Significant at the (.01) level. Sig. :Significance.

**Significant at the (.01) level. N.Sig:Non significance.

IQR : Inter quartile range.
From the above table it is clear:

\section{1- VSS (Standard score): Pre, treatment}

There is no statistically significant difference between Group) A and B (as a ( $\mathrm{Z}$ ) value equal (0.542) and the $p$-value is $(0.12)$ which more than $(0.05)$.

\section{2- VSS (Standard score): Post, treatment}

There is statistically significant difference between Group) Control and Study (as a ( $Z$ ) value equal (2.963) and the $\mathrm{P}$-value is $(0.003)$ which less than $(0.01)$. That for the benefit for (Group A), where the Median equal (5), while Median equal (9), to the (Group B).

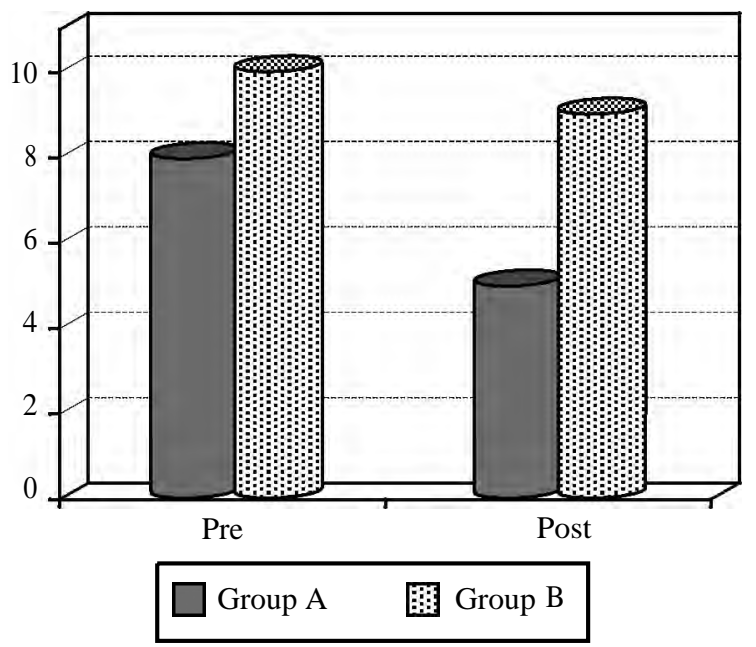

Fig (3): Comparison of the difference between groups (A and $\mathrm{B})$.

\section{Discussion}

Burns are caused by exposure to excessive heat as flame, hot surfaces, scalding liquids, friction, electricity and chemical burns [1]

The basic pathophysiological consequence of the burn injury is the loss of the capillary integrity, localized increase in the micro vascular permeability, generalized impairment in the cell membrane resulting in swelling and increase osmotic press. Of the burned tissue leading to further fluid accumulation and edema formation, which is a result of the outpouring of the intravascular fluid into the interstitial spaces [2].

Hypertrophic scars occur when the body overproduces collagen, which causes the scar to be raised above the surrounding skin. Hypertrophic scars take the form of a red raised lump on the skin. They usually occur within 4 to 8 weeks following wound infection or wound closure with excess tension and/or other traumatic skin injuries [3]. 
"Micro pore" is a trade mark for micro porous tape sold by $3 \mathrm{M}$, it is a self-adhesive tape which adheres to the skin when a contact medium has been applied to it. This provides a significant advantage over a fully occlusive material which promotes bacterial proliferation [4].

Micro porous paper tape is gaining attention in scar prevention. However, in current standard practice, paper tape is used for only a few weeks to support surgical scars after suture removal. It is proposed that long-term use of paper tape, until approximately 12 weeks after wounding, would allow maximum strength of scar, which would be beneficial in preventing hypertrophic scarring [s

This study was conducted to investigate the effectiveness of micropore tape in treatment of hypertrophic scar after wrist burn.

The results showed that there is significant difference in Vancouver scar scale in group A pre and Post treatment and there is significant difference in Vancouver scar scale in group B pre and post treatment and there is a significant difference in Vancouver scar scale between group A and B pre and post treatment as group A improved more than group B. It can concluded that that micropore tape with physical therapy treatment have effect on hypertrophic scar after wrist burn more than physical therapy only.

The results of this study agreed whit [6] who found that the conduction of a controlled trial to compare skin closure using conventional interrupted sutures with a combination of subcuticular suture and sterile Micropore tape in 169 patients undergoing appendectomy, inguinal herniorrhaphy, or saphenofemoral ligation. They have found that the combination technique consistently gives a better cosmetic result and that the tape acts well as a dressing, is convenient, and is well tolerated by patients.

The results of this study also agreed with [4] who found that Longitudinal stretching of wounds that cross the relaxed skin tension lines appears to be the stimulus that causes the body to form hypertrophic scars. Control or elimination of such stretching forces by the long-term use of paper tape, beginning at 2 weeks, has been effective in preventing such hypertrophic scarring.

The results of this study also agreed with [7] who found that Paper tape to support the scar may reduce multidirectional forces and prevent hypertrophic scarring.

The results of this study also agreed with [8] who found that the use of both tissue expanders and skin-stretching devices is Commonplace in reconstructive surgery.

The results of this study also agreed with [9] who found that Specific scar taping is able to enhance the maturation of the scar and manage the related symptoms.

The results of this study disagree with [10] who found that taped closure alone has advantages of lower wound infection rates and greater wound tensile strength, but disadvantages of epidermal reaction, skin edge inversion, doubtful safety and time required for meticulous surgical technique. There is no evidence in the scientific literature to justify or support the practice of closing a surgical wound with both subcuticular suture and adhesive surgical tape.

\section{References}

1- CIVAIA A., FEDELE C., GALLINO A. and OLIVIA R. :'The rehabilitative management of burn patients in the post acute phase". Annals of burns and fire Disasters March, Vol. XVI-n. 1., 2003

2- FLANAGAN M.: "The physiology of wound healing". Journal of Wound Care, 9 (6): 290-300, 2000.

3- GAUGLITZ G.G., KORTING H.C., PAVICIC T., RUZICKA T. and JESCHKE M.G.: "Hypertrophic Scarring and Keloids: Pathomechanisms and Current and Emerging Treatment Strategies". Mol. Med., 17 (1-2): 113-125, 2011.

4- REIFFEL R.S.:" Prevention of hypertrophic scars by longterm paper tape application". Plast. Reconstr. Surg., 96 (7): 1715-1718, 1995.

5- MEYER M. and McGROUTHER D.A.: "A study relating wound tension to scar morphology in the pre-sternal scar using Langers technique.” Br. J. Plast. Surg., 44 (4): 291294, 1991.

6- TAUBE M.F., PORTER R.J. and LORD P.H.: A combination of subcuticular suture and sterile Micropore tape compared with conventional interrupted sutures for skin closure. Royal college of surgeons of England, Vol. 65, 1983.

7- ATKINSON J.A., McKENNA K.T., BARNETT A.G., McGRATH D.J. and RUDD M.: "A randomized, controlled trial to determine the efficacy of paper tape in preventing hypertrophic scar formation in surgical incisions that traverse Langer's skin tension lines". Plast. Reconstr. Surg., 116 (6): 1648-1656, 2005.

8- MAHENDRA D. and NAIR V.: Traction assisted dermatogenesis by serial intermittent skin tape application. Plast. Reconstr. Surg., 122 (4): 1047-1054, 2008.

9- MAHENDRA D.: Abnormal scar modulation with the use of Micropore Tape ". European Journal of Plastic Surgery, 34 (1): 45-51, 2010.

10- JEREMY D.K.: "Use of adhesive surgical tape with the absorbable continous subcuticular suture". ANZ J. Surg., 73: 626-629, 2003. 


\section{تأثير لاصق الميكروبور على علاج ندبات

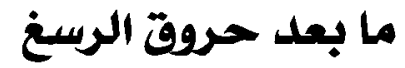

أجريت هذه الدراسة لمعرفة تأثير لاصق الميكربود على علاج ندبات ما بعد حرق الرسغ.

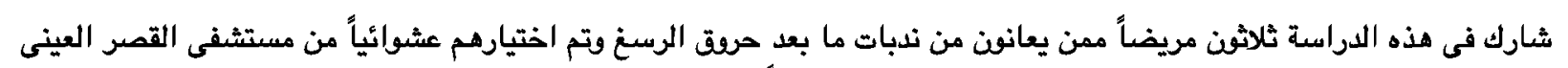

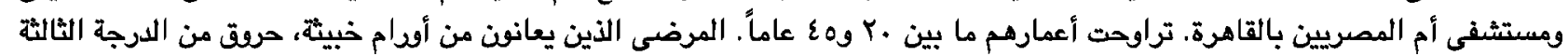
فى الرسغ والمرضى الذين يعانون من • ب٪ حرق أكثر من مساحة الجسم الكلية تم استبعادهم من الدراسة.

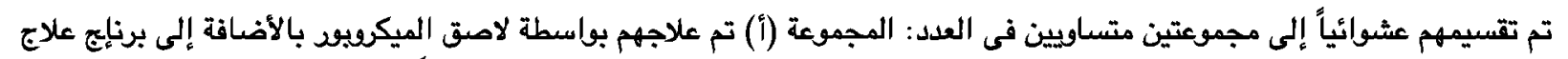

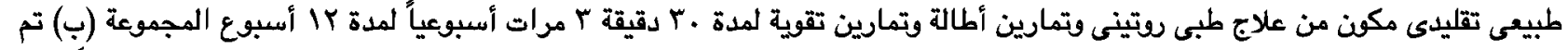

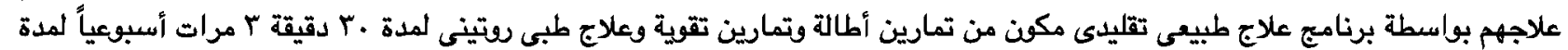
(r)

تم قياس الأصطباغ، الأوعية الدموية، مرونة وطول الندبة عن طريق مقياس فانكوفر وتم قياس مدى حركة مفصل الرسنغ بواسطة الجينيوميتر قبل وبعد العلاج.

أوضحت نتائج هذه الدراسة أن هناك تحسن ذو دلالة إحصائية فى مفصل الرسن في حركتى الثنى والفرد في المجموعتين (أ) و (ب) قبل فيل

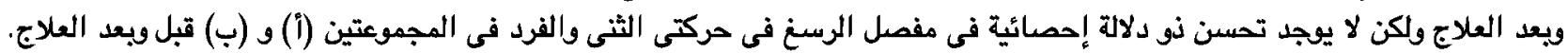

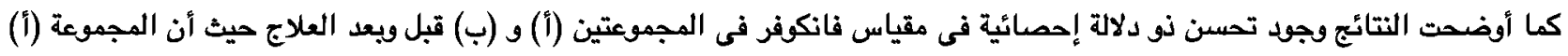
تصسنت بنسبة أكبر من المجموعة (ب). لذلك يمكن أن نستخلص أن لاصق الميكربيو بالأضافة إلى تمارين العلاج الطبيعى التقليدية لها تأثير إيجابى على الندبة بعد حرق الرسخ أكثر من التمارين العلاجية فقط. 